\title{
ANALISIS KEMAMPUAN PEMECAHAN MASALAH MAHASISWA DALAM MATA KULIAH MATEMATIKA DISKRIT PADA MATERI KOMBINATORIKA
}

\section{ANALYSIS OF STUDENTS' PROBLEM SOLVING ABILITIES IN DISCRETE MATHEMATICS SUBJECTS IN COMBINATORICS MATERIAL}

\author{
Evi Triyani ${ }^{a}$, Heni Pujiastutib \\ aProgram Studi Pendidikan Matematika FKIP UNTIRTA \\ Jl. Raya Jkt Km 4 Jl. Pakupatan, Panancangan, Kec. Cipocok Jaya, Kota Serang, Banten \\ 42124, triyanievi1@gmail.com

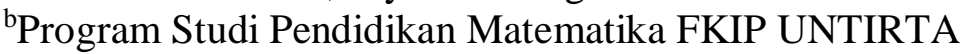 \\ Jl. Raya Jkt Km 4 Jl. Pakupatan, Panancangan, Kec. Cipocok Jaya, Kota Serang, Banten \\ 42124, henipujiastuti@untirta.ac.id
}

\begin{abstract}
ABSTRAK
Penelitian ini bertujuan untuk mengetahui kemampuan pemecahan masalah dalam mata kuliah matematika diskrit pada materi kombinatorika mahasiswa semester VI Pendidikan Matematika di Universitas Sultan Ageng Tirtayasa. Jenis penelitian ini yaitu penelitian deskriptif kualitatif. Dimana penelitian ini mendeskripsikan hasil dari analisis pemecahan masalah pada mahasiswa. Sampel yang digunakan dalam penelitian ini sebanayak 10 mahasiswa. Instrumen yang digunakan yaitu tes uraian kemampuan pemecahan masalah pada kombinatorika dan dilakukan wawancara. Hasil dalam penelitian ini menunjukkan bahwa 1) Tingkat kemampuan pemecahan masalah mahasiswa dalam materi kombinatorika rata-ratanya adalah 69, dimana masuk pada klasifikasi Cukup Baik; 2) Terdapat faktor yang membuat mahasiswa sulit untuk menyelesaikan pemecahan masalah kombinatorika, yaitu faktor lupa mengerjakan dengan rumus apa dan faktor bingung untuk mengidentifikasi permasalahan kombinatorika tersebut. Kemampuan pemecahan masalah dalam kombinatorika dapat diselesaikan dengan mudah apabila sering berlatih.
\end{abstract}

Kata Kunci : Kemampuan Pemecahan Masalah, Kombinatorika, Deskriptif Kualitatif

\begin{abstract}
This study aims to determine the ability of problem solving in discrete mathematics courses on combinatorics material for the sixth semester students of Mathematics Education at Sultan Ageng Tirtayasa University. This type of research is a qualitative descriptive study. Where this study describes the results of the analysis of problem solving in students. The sample used in this study were 10 students. The instrument used was a test description of the ability to solve problems in combinatorics and interviews. The results in this study indicate that 1) The average level of problem solving abilities of students in combinatorics material is 69 , which is included in the classification Good Enough; 2) There are factors that make it difficult for students to solve combinatorics problem solving, namely the factor of forgetting to work with what formulas and the confused factor to identify these combinatorics problems. Combinatorics problem solving skills can be easily resolved if you practice frequently.
\end{abstract}

Keywords : Problem Solving, Combinatorics, Descriptive Qualitative Ability 


\section{Pendahuluan}

Matematika merupakan pelajaran yang telah dilakukan sejak duduk di bangku Sekolah Dasar hingga Perguruan Tinggi. Matematika juga merupakan ilmu pengetahuan yang dibutuhkan bagi semua kalangan. Matematika sangat diperlukan untuk kehidupan sehari-hari, seperti berhitung dan menyimpulkan (Hayu, Linna, Maimunah, \& Roza, 2019). Matematika merupakan dasar dari semua ilmu peengetahuan, oleh karena itu matematika sudah dikenalkan sejak dini yakni mulai dari pendidikan Taman Kanak-kanak sampai jenjang perguruan tinggi (Novianti, Khoirotunnisa, \& Indriani, 2017). Perguruan Tinggi merupakan pelaksana pendidikan yang tertinggi sekaligus ujung tombak pelaksana tujuan pendidikan (Septian, 2017).

Dalam perguruan tinggi, salah satu fakultas yang ada di dalamnya yaitu Fakultas Keguruan dan Ilmu Pendidikan dimana di dalamnya terdapat program studi Pendidikan Matematika. Pada program studi Pendidikan Matematika, salah satu mata kuliah wajib yaitu Matematika Diskrit. Dimana Matematika Diskrit merupakan mata kuliah wajib 3 sks yang harus diikuti oleh mahasiswa Pendidikan Matematika Fakultas Keguruan dan Ilmu Pendidikan Universitas Sultan Ageng Tirtayasa.
Dalam mata kuliah tersebut membahas mengenai materi diantaranya logika, himpunan, matriks, relasi, fungsi, induksi matematik, algoritma dan kombinatorika.

Dalam materi kombinatorika, berdasarkan pengalaman peneliti, dimana peneliti telah mengambil mata kuliah matematika diskrit yang mana masih banyak kesulitan dalam memecahkan masalah khusunya materi kombinatorika. Padahal dalam materi kombinatorika banyak masalah yang berkaitan dengan kehidupan sehari-hari. Materi kombinatorika sendiri telah dilakukan pada saat duduk di bangku SMP dan SMA. Namun, masih terdapat mahasiswa yang belum sepenuhnya mengerti atau kebingungan bagaimana cara mengubah permasalahan kombinatorika menjadi bentuk matematika dan masih banyak kesulitan dalam menyelesaikan masalah kombinatorika (Sumargiyani, Yusnia, \& Adibah, 2019). Kombinatorika merupakan satu cabang ilmu matematika yang mempelajari pengaturan objek-objek (Sulistyorini, Argarini, \& Yazidah, 2018). Dalam hal ini pemecahan masalah pada materi kombinatorika memerlukan kemampuan dalam berpikir analitik dan dalam hal ini siswa cenderung merasa kebingungan untuk memecahkan masalah-masalah kombinatorial tersebut. Berdasarkan hasil penelitian, terdapat beberapa mahasiswa yang 
mengalami kesulitan dalam menyelesaikan soal matematika khususnya pada mata kuliah matematika diskrit materi kombinatorika (Wahyuniar \& Widyawati, 2017). Ada beberapa mahasiswa yang dalam memecahkan suatu masalah menggunakan cara lama pada masa sekolahnya dahulu, atau dengan berdiskusi dengan temannya (Herlina \& Dahlia, 2018). Dari hasil penelitian di atas dapat dikatakan bahwa salah satu tujuan dalam pembelajaran matematika yaitu agar dapat memecahkan suatu masalah khususnya pada materi kombinatorika.

Pemecahan masalah merupakan aspek pengetahuan yang sangat penting dalam pembelajaran karena dengan cara memecahkan masalah dapat membuat mahasiswa mengasah kemampuan berpikir seacara kritis (Ambarwati, 2016). Kemampuan pemecahan masalah matematis merupakan suatu kemampuan yang sangat penting yang harus dimiliki oleh mahasiswa, karena kemampuan ini menempati sebagai tujuan umum dan tujuan utama dalam pembelajaran matematika (Darma, Firdaus, \& Haryadi, 2016).

Berdasarkan hasil uraian di atas menunjukkan bahwa kemampuan pemecahan masalah merupakan salah satu kemampuan yang sangat penting dalam pembelajaran matematika. Karena dengan kemampuan pemecahan masalah dapat meningkatkan kemampuan berpikir analitik sehingga berpikir kritis nya dapat meningkat.

Kemampuan memecahkan masalah matematis termasuk dalam berpikir matematis tingkat tinggi dan kemampuan ini sangat penting karena berhubungan dalam kehidupan sehari-hari (Darminto, 2013). Sehingga diperlukan penjelasan yang lebih mendalam mengenai kemampuan pemecahan masalah.

Dengan pemecahan masalah matematika, siswa tidak akan kehilangan makna dalam mempelajari matematika karena suatu konsep atau prinsip akan bermakna jika konsep atau prinsip tersebut dapat diaplikasikan dalam suatu pemecahan masalah (Widodo, 2013). Kemampuan pemecahan masalah sendiri dalam matematika harus bisa dikuasai oleh mahasiswa. Karena dengan pemecahan masalah dapat merangsang berpikir kritis nya, dan dapat melatih suatu saat nanti ketika telah menjadi seorang pendidik agar dapat menjelaskan secara detail dan jelas kepada peserta didiknya.

Pemecahan masalah memiliki tiga interpretasi yaitu: pemecahan masalah (1) sebagai suatu tujuan utama, (2) sebagai sebuah proses, dan (3) sebagai keterampilan dasar (Netriwati, 2016). Dilihat dari ketiga interpretasi itu sangat 
harus di implementasikan. Pertama, pemecahan masalah sebagai tujuan utama yaitu pemecahan masalah harus bisa memecahkan suatu masalah sampai berhasil. Kedua, sebagai sebuah proses dimana dalam pemecahan masalah ini harus dilakukan dengan melihat prosedur atau langkah-langkah. Dan yang ketiga, pemecahan masalah sebagai keterampilan dasar dimana dengan terbiasa melakukan pemecahan masalah maka akan muncul keterampilan dalam memecahkan masalah. Di samping itu, perlu diketahui bahwa pemecahan masalah sebagai suatu usaha mencari jalan keluar dari suatu kesulitan atau suatu masalah guna mencapai tujuan yang tidak begitu mudah dapat dicapai (Hadi \& Radiyatul, 2014). Dalam memecahkan masalah matematis diperlukan langkah-langkah sebagai berikut: (1) memahami masalah (understanding the problem), merencanakan penyelesaian (devising a plan), (3) melaksanakan rencana (carrying out the plan), dan (4) memeriksa kembali proses dan hasil (looking back) Polya (Amalia \& Widodo, 2018).

Berdasarkan pemamparan di atas, dalam penelitian ini akan diteliti dan dianalisis mengenai kemampuan pemecahan masalah matematis pada mahasiswa dalam menyelesaikan soal matematika diskrit materi kombinatorika dan faktor-faktor apa saja yang membuat mahasiswa melakukan kesalahan dalam memecahkan masalah pada materi kombinatorika.

Berdasarkan uraian rumusan masalah di atas, maka didapat tujuan penelitian yaitu:

1. Untuk menganalisis kemampuan pemecahan masalah matematis pada mahasiswa dalam menyelesaikan soal matematika diskrit materi kombinatorika

2. Untuk mengetahui faktor-faktor yang membuat mahasiswa melakukan kesalahan dalam memecahkan masalah pada materi kombinatorika.

Sehingga informasi yang diperoleh dari hasil penelitian nanti dapat membuat mahasiswa untuk mengembangkan atau meningkatkan kemampuan pemecahan masalah matematis. Dengan begitu peneliti bermaksud melakukan penelitian yang diteliti dan dianalisis mengnai "Analisis Kemampuan Pemecahan Masalah Mahasiswa dalam Mata Kuliah Matematika Diskrit pada Materi Kombinatorika”.

\section{Metode Penelitian}

Metode yang digunakan dalam penelitian ini adalah metode deskriptif kualitatif. Dimana penelitian deskriptif kualitatif merupakan penelitian yang melakukan analisis hanya samapai proses mendeskripsikan, yaitu dengan 
menganalisis secara sistematik dan berurut. Dalam penelitian ini akan mendeskripsikan hasil dari rata-rata kemampuan pemecahan masalah dalam menyelesaikan soal matematika diskrit materi kombinatorika.

Subjek dalam penelitian ini adalah mahasiswa semester VI program studi Pendidikan Matematika Fakultas Keguruan dan Ilmu Pendidikan Universitas Sultan Ageng Tirtayasa yang terdiri dari 10 mahasiswa dengan kemampuan yang berbeda.

Instrumen yang akan digunakan dalam penelitian ini adalah Tes dan Wawancara. Tes yang digunakan yaitu berupa tes uraian. Tes dibuat berdasarkan indikator kemampuan pemecahan masalah antara lain (1) memahami masalah (understanding the problem), (2) merencanakan penyelesaian (devising a plan), (3) melaksanakan rencana (carrying out the plan), dan (4) memeriksa kembali proses dan hasil (looking back). Sedangkan untuk wawancara dilakukan pada 3 mahasiswa yang hasil tes uraiannya masuk kategori tinggi, sedang, dan rendah. Wawancara yang digunakan yaitu wawancara yang tidak terstruktur.

Teknik analisis data yaitu dengan menggunakan statitika sederhana (deskriptif). Analisis deskriptif berdasarkan hasil kemampuan pemecahan masalah dengan rumus:
Skor tiap mahasiswa

$$
N=\frac{\text { Jumlah Setiap Skor }}{5} \times 10
$$

Rata-rata seluruh mahasiswa

$$
=\frac{\text { Jumlah Seluruh Nilai Mahasiswa }}{\text { Banyak Mahasiswa }}
$$

Sebagai pengambilan kesimpulan dari analisis data dengan mengacu pada pendapat (S, 2019), seperti tabel 1 berikut:

Tabel 1. Kategori Kemampuan

Pemecahan Masalah

\begin{tabular}{ccc}
\hline No & Kategori & Klasifikasi \\
\hline 1 & $85<\mathrm{N}<100$ & Sangat Baik \\
2 & $70<\mathrm{N}<85$ & Baik \\
3 & $55<\mathrm{N}<70$ & Cukup Baik \\
4 & $40<\mathrm{N}<55$ & Kurang Baik \\
5 & $0<\mathrm{N}<40$ & Tidak Baik \\
\hline \multirow{3}{*}{ Sumber : $(\mathrm{S}, 2019)$}
\end{tabular}

\section{Hasil dan Pembahasan}

Dalam pengambilan data, peneliti melakukan penelitian pada mahasiswa semester VI sebanyak 10 orang. Peneliti meminta mahasiswa untuk mengerjakan lima soal kombinatorika. Selain itu, akan dilakukan wawancara kepada tiga mahasiswa yang termasuk kedalam kategori baik, cukup baik, dan kurang baik. Wawancara dilakukan untuk memperkuat hasil dari tes uraian.

Hasil analisis data dari kemampuan pemecahan masalah pada materi kombinatorika mahasiswa semester VI Pendidikan Matematika dapat dilihat pada tabel 2 di bawah ini: 
Tabel 2. Rata-rata Kemampuan

Pemecahan Masalah Mahasiswa

\begin{tabular}{|c|c|c|c|}
\hline No & Mahasiswa & Nilai & Klasifikasi \\
\hline 1 & M1 & 82 & Baik \\
\hline 2 & M2 & 78 & Baik \\
\hline 3 & M3 & 78 & Baik \\
\hline 4 & M4 & 74 & Baik \\
\hline 5 & M5 & 74 & Baik \\
\hline 6 & M6 & 72 & Baik \\
\hline 7 & M7 & 70 & Cukup Baik \\
\hline 8 & M8 & 60 & Cukup Baik \\
\hline 9 & M9 & 58 & Cukup Baik \\
\hline 10 & M10 & 44 & Kurang Baik \\
\hline \multicolumn{2}{|c|}{ Jumlah rata-rata } & 69 & Cukup Baik \\
\hline
\end{tabular}

Dilihat dari tabel menunjukkan bahwa dari 10 mahasiswa yang diteliti, memperlihatkan hasil kemampuan pemecahan masalah pada materi kombinatorika termasuk ke dalam klasifikasi Cukup Baik dengan menunjukkan nilai rata-rata sebesar 69 . Kemudian diklasifikasikan menurut kategori, sehingga didapat bahwa 6 mahasiswa termasuk klasifikasi Baik, 3 mahasiswa termasuk klasifikasi Cukup Baik, dan 1 mahasiswa termasuk klasifikasi Kurang Baik. Wawancara dilakukan pada 3 orang dari perwakilian setiap klasifikasi. M1 dari mahasiswa klasifikasi Baik, M8 dari mahasiswa klasifikasi Cukup Baik, dan M10 dari mahasiswa klasifikasi Kurang Baik.

Hasil dari pengerjaan soal tes kemampuan pemecahan masalah pada materi kombinatorika dari 10 mahasiswa rata-rata menjawab soal nomor 2 dengan tepat. Selain itu, rata-rata dari mahasiswa yang menjawab salah terdapat pada soal nomor 5. Begitupun dengan M1, M8, dan M10 memperlihatkan bahwa mereka dapat menyelesaikan soal nomor 2 dengan tepat. Soal 2 : "Berapa banyak cara membagikan 10 buah jeruk kepada 3 orang anak, bila Bagus mendapat 4 buah jeruk dan Eka serta Aryana masingmasing mendapat 3 buah jeruk? ". Seperti gambar di bawah ini:

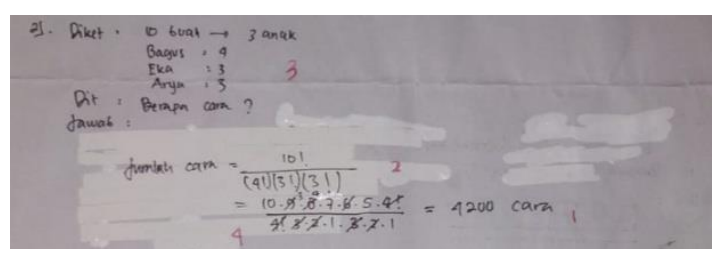

Gambar 1. Jawaban nomor 2 M1

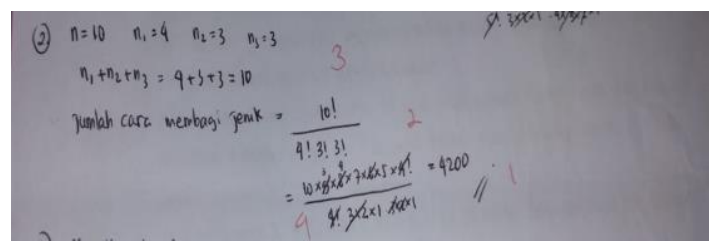

Gambar 2. Jawaban nomor 2 M8

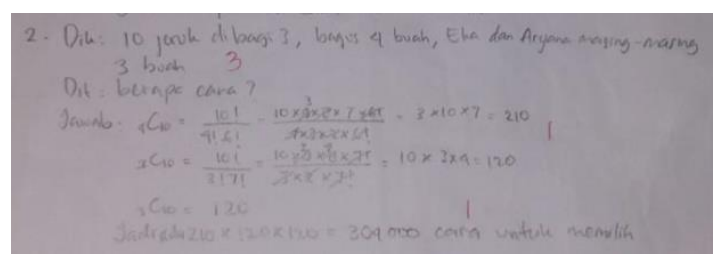

Gambar 3. Jawaban nomor 2 M10

Dilihat dari gambar di atas memperlihatkan bahwa mahasiswa tersebut telah menyelesaikan dengan tepat dan sudah sesuai dengan indikator kemampuan pemecahan masalah menurut Polya. Dimana pada pengerjaannya sudah secara jelas benar, dan menyelesaikannya 
dengan tepat. Tetapi untuk gambar 3 masih terdapat kesalahan dalam membuat starategi untuk menyelesaikan permasalahan tersebut. Sehingga pada mahasiswa M10 belum tepat untuk membuat kesimpulan permasalahan kombinatorika tersebut.

Selain soal nomor 2 dengan ratarata jawaban yang tepat, terdapat soal yang rata-rata mahasiswanya menjawab salah seperti soal nomor 5. Soal 5 : "Dalam berapa banyak cara huruf-huruf $a, b, c, d, e, f$ dapat disusun jika huruf $b$ harus disebelah kiri dan bersebelahan dengan huruf $e$ ?". Seperti gambar di bawah ini:

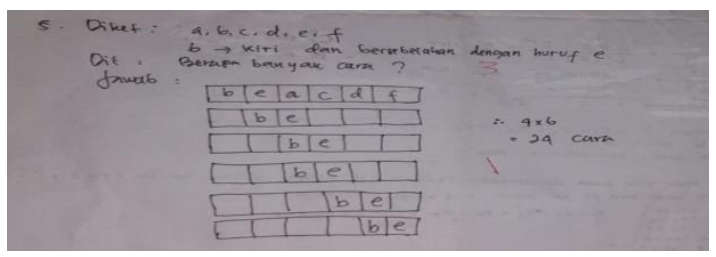

Gambar 4. Jawaban nomor 5 M1

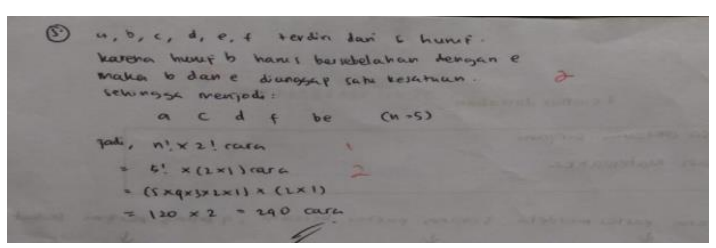

Gambar 5. Jawaban nomor 5 M8

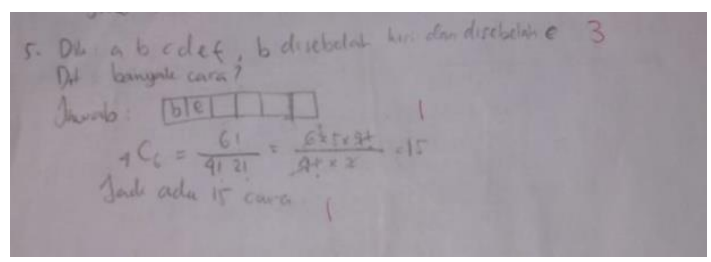

Gambar 6. Jawaban nomor 6 M10

Dilihat dari gambar di atas memperlihatkan bahwa penyelesaian yang dilakukan salah. Sebenarnya untuk mahasiswa M1 sudah melakukan pemecahan masalah yang sesuai tetapi dalam menyelesaikannya kurang tepat sehingga dalam menyimpulkan permasalahan tersbeut belum tepat.

Berdasarkan hasil penelitian di atas, maka pembahasan dari data di atas diperoleh bahwa dalam menyelesaikan soal pemecahan masalah kombinatorika masih ada yang kurang tepat, atau tidak sesuai dengan indikator pemecahan masalah. Berikut ini akan dibahas bagaimana langkah-langkah pemecahan masalah yang dilakukan oleh mahasiswa pada materi kombinatorika.

a. Kemampuan Pemecahan Masalah Kategori Baik

Pada mahasiswa dengan kemampuan pemecahan masalah baik diperoleh ulasan sebagai berikut:

1. Memahami Masalah

Dalam memahami masalah mahasiswa mampu mengungkapkan apa yang diketahui dan ditanyakan dengan tepat. Mahasiswa juga mampu mengungkapkan informasi yang belum terlihat disoal untuk membantu memahami masalah.

2. Merencanakan Penyelesaian

Mahasiswa sudah mampu menentukan antara yang diketahui dan ditanyakan sehingga mahasiswa dapat 
membuat rencana untuk memecahkan masalah.

3. Menyelesaikan Masalah

Mahasiswa mampu menyelesaikan sesuai dengan langkah-langkah pada rencana masalah yang telah dibuat.

4. Melakukan Pengecekan

Mahasiswa dapat menentukan solusi untuk memecahkan masalah, dengan langkah-langkah rencana yang telah dibuat.

b. Kemampuan Pemecahan Masalah Kategori Cukup Baik

Pada mahasiswa dengan kemampuan pemecahan masalah cukup baik diperoleh ulasan sebagai berikut:

1. Memahami Masalah

$$
\text { Dalam memahami }
$$

masalah mahasiswa mampu mengungkapkan apa yang diketahui dan ditanyakan dengan tepat. Mahasiswa juga mampu mengungkapkan informasi yang belum terlihat disoal untuk membantu memahami masalah.

2. Merencanakan Penyelesaian

Mahasiswa sudah mampu menentukan antara yang diketahui dan ditanyakan. Tetapi mahasiswa belum dapat membuat rencana dengan tepat untuk memecahkan masalah.
3. Menyelesaikan Masalah

Mahasiswa belum

mampu menyelesaikan sesuai

dengan langkah-langkah pada

rencana masalah yang telah

dibuat. Karena pemahaman terhadap materi kurang menguasai.

4. Melakukan Pengecekan

Mahasiswa tidak dapat menentukan solusi untuk memecahkan masalah karena merasa kesulitan.

c. Kemampuan Pemecahan Masalah Kategori Kurang Baik

Pada mahasiswa dengan kemampuan pemecahan masalah kurang baik diperoleh ulasan sebagai berikut:

1. Memahami Masalah

$$
\text { Dalam memahami }
$$

masalah mahasiswa belum memahami masalah dengan baik. Mahasiswa mampu mengungkapkan apa yang diketahui dan ditanyakan dengan tepat. Namun mahasiswa belum mampu mengungkapkan informasi yang belum terlihat disoal untuk membantu memahami masalah.

2. Merencanakan Penyelesaian Mahasiswa belum mampu menentukan antara yang diketahui dan ditanyakan. 
Sehingga mahasiswa belum dapat membuat rencana dengan tepat untuk memecahkan masalah.

3. Menyelesaikan Masalah

Mahasiswa
mampu menyelesaikan sesuai
dengan langkah-langkah pada
rencana masalah yang telah
dibuat. Karena pemahaman
terhadap materi kurang
menguasai dan rencana yang
dibuat dari awal sudah tidak
tepat.

4. Melakukan Pengecekan

Mahasiswa tidak dapat menentukan solusi untuk memecahkan masalah karena merasa kesulitan dan tidak memeriksa kembali jawabannya. Sehingga dalam menyelesaikan suatu permasalahan terjadi kesalahan perhitungan yang mengakibatkan tidak membuat kesimpulan dari permasalahan kombinatorika tersebut.

Berdasarkan uraian di atas, terlihat bahwa adanya kaitan antara kemampuan pemecahan masalah dengan berpikir logika pada materi kombinatorika. Dimana mahasiswa dengan kemampuan pemecahan masalah baik mampu menentukan yang diketahui dan ditanyakan, mampu menyelesaikan langkah-langkah pemecahan masalah dengan baik. Dalam membuat rencana pemecahan masalah, carilah hubungan antara informasi yang diberikan dengan yang tidak diketahui yang memungkinkan untuk menyelesaikan permasalahan (Karlimah, 2010).

Mahasiswa dalam menyelesaikan masalah dengan kemampuan pemecahan masalah telah melakukan sesuai dengan langkah-langkah yang direncanakan. Dimana memikirkan atau menelaah kembali langkah-langkah yang telah dilakukan dalam pemecahan masalah merupakan kegiatan yang penting untuk mendapatkan hasil yang tepat (Yuwono, Supanggih, \& Ferdiani, 2018).

Pada mahasiswa dengan kemampuan pemecahan masalah baik telah menunjukkan bahwa mahasiswa telah memahami mengenai permasalahan yang diberikan. Sehingga dapat menyelesaikan rencana permasalahan dan mendapatkan hasil yang tepat. Untuk mahasiswa dengan kemampuan cukup baik masih terdapat kesalahan dalam menyelesaikannya. Sedangkan untuk mahasiswa dengan kemampuan kurang baik masih melakukan kesalahan pada saat merencanakan masalah sehingga tidak dapat mendapatkan kesimpulan yang tepat. Didukung dengan hasil pembahasan yang mengatakan bahwa mahasiswa dengan kemampuan kategori baik telah 
mampu melakukan langkah-langkah pemecahan masalah dengan baik sehingga mendapatkan hasil yang tepat (Mahardhikawati, Mardiyana, \& Setiawan, 2017).

Kategori kemampuan pemecahan masalah cukup baik, dan kemampuan pemecahan masalah kurang baik mahasiswa telah membuat rencana penyelesaian namun masih belum tepat sehingga tidak dapat menyebutkan penyelesaiannya (Widiyastuti \& Utami, 2017).

Berdasarkan pernyataan di atas, didukung pula dengan hasil wawancara yang dilakukan pada mahasiswa M1, M8, dan M10. Dimana hasil wawancara dari mahasiswa M1 mengatakan bahwa saat mengerjakan soal kombinatorika mengerjakannya lupa-lupa ingat. Pada saat membaca soal langsung di identifikasi apa saja yang diketahui dan ditanyakan. Dan untuk soal yang mudah terdapat pada soal 2, dan soal tersulit pada soal 5. Faktor yang membuat sulit dalam menyelesaikan soal tersebut yaitu karena bingung, dan lupa harus menggunakan rumus apa.

Pada mahasiswa M8 juga mengatakan soal yang termudah terdapat pada soal 2, karena mudah untuk di identifikasi. Tetapi untuk soal yang sulit terdapat pada soal 1. Faktor yang membuat sulit yaitu bingung mengidentifikasikannya. Sedangkan untuk mahasiswa M10 mengatakan soal termudah juga terdapat pada soal 2, karena pada saat membaca soal tersebut langsung dapat menentukan rumus yang digunakan. Dan untuk soal tersulit yaitu soal 4. Faktor yang membuat sulit karena bingung untuk menyelesaikannya.

Hasil dari wawancara tersebut mendukung bahwa rata-rata mahasiwa mengatakan soal termudah yaitu pada soal 2. Selain itu, soal yang tersulit yaitu pada soal 5. Hasil dari wawancara dapat memperkuat hasil dari penelitian, dan dilakukan pada mahasiswa dengan hasil kemampuan pemecahan masalah yang berbeda-beda (Anam, Suharto, Murtikusuma, Hobri, \& Oktavianingtyas, 2018). Ada beberapa faktor yang membuat mahasiswa merasa kesulitan untuk menyelesaikan permasalahan kombinatorial, diantaranya yaitu 1) karena lupa harus menggunakan rumus apa, 2) bingung harus mengidentifikasi unsur apa saja yang diketahui dan ditanyakan.

Melalui pemecahan masalah, mahasiswa diharapkan dapat memperoleh pengalaman belajar dalam menjelaskan setiap langkah dari suatu permasalahan (Wahyuddin, 2017). Dengan mendorong mahasiswa secara dalam dengan kegiatan pemecahan masalah maka akan dapat mengasah berpikir secara logika. Hasil penelitian ini mendukung pendapat bahwa 
kemampuan pemecahan masalah pada materi kombinatorika dapat mengasah kemampuan berpikir logika (Zulkarnain \& Nurbiati, 2019). Sehingga apabila mahasiswa dengan kemampuan pemecahan masalah masuk kategori baik maka berpikir logikanya baik.

\section{Kesimpulan}

Kesimpulan dari hasil penelitian ini antara lain:

1. Rata-rata kemampuan pemecahan masalah mahasiswa dalam materi kombinatorika yaitu sebesar 69. Dimana rata-rata tersebut termasuk ke dalam klasifikasi Cukup Baik.

2. Untuk menyelesaikan pemecahan masalah pada kombinatorika terdapat beberapa faktor yang mempengaruhi diantaranya yaitu, faktor lupa menggunakan rumus dan faktor bingung untuk mengidentifikasi unsur yang diketahui dan ditanyakan.

\section{Ucapan Terimakasih}

Dalam penelitian ini, peneliti berterimakasih kepada mahasiswa Pendidikan Matematika semester VI di Universitas Sultan Ageng Tirtayasa yang telah bersedia menjadi sampel dalam penelitian ini. Tak lupa juga peneliti berterimakasih kepada semua orang yang terlibat dalam penulisan ini.

\section{Pustaka}

Amalia, S. R., \& Widodo, A. N. (2018). Analisis kemampuan Pemecahan Masalah Mahasiswa Melalui Model Pbl Berbasis

Etnomatematika Ditinjau dari Kepribadian Topologi Hippocrates, Galenus Tipe Cholearis dan Phlegmantis. Aksioma , 1-10.

Ambarwati, M. (2016). Analisis Kemampuan Pemecahan Masalah Dalam Strategi Think Talk Write (TTW). Jurnal Pedagogia , 239246.

Anam, M. K., Suharto, Murtikusuma, R. P., Hobri, \& Oktavianingtyas, E. (2018). Analisis Kemampuan Pemecahan Masalah Matematika Siswa Berdasarkan Teori APOS (Action, Process, Object, Schema) Ditinjau Dari Tipe Kepribadian Florence Littauer. Kadikma , 4958.

Darma, Y., Firdaus, M., \& Haryadi, R. (2016). Hubungan Kemandirian Belajar Terhadap Kemampuan Pemecahan Masalah Matematis Mahasiswa Calon Guru Matematika. Jurnal Edukasi, 169178.

Darminto, B. P. (2013). Meningkatkan Kemampuan Pemecahan Masalah Matematis Mahasiswa Melalui 
Pembelajaran Model Treffinger.

Jurnal Pendidikan Matematika dan Sains , 101-107.

Hadi, S., \& Radiyatul. (2014). Metode Pemecahan Masalah Menurut Polya Untuk Mengembangkan Kemampuan Siswa Dalam Pemecahan Masalah Matematis Di Sekolah Menengah Pertama. EDU-MAT Jurnal Pendidikan Matematika, 53-61.

Hayu, E., Linna, R., Maimunah, \& Roza, Y. (2019). Analisis Kemampuan Koneksi Matematis Siswa Dalam Menyelesaikan Masalah Pada Materi Perbandingan. AdMathEdu , 11-20.

Herlina, S., \& Dahlia, A. (2018). Analisis

Kemampuan Berpikir Kritis Matematis Mahasiswa Calon Guru Ditinjau Dari Cognitive Style Berdasarkan Field Independent Dan Field Dependent Di Universitas Islam Riau . AdMathEdu , 35-48.

Karlimah. (2010). Pengembangan Kemampuan Komunikasi dan Pemecahan Masalah Serta Disposisi Matematis Mahasiswa PGSD Melalui Pembelajaran Berbasis Masalah.

Mahardhikawati, E., Mardiyana, \& Setiawan, R. (2017). Analisis Kemampuan Pemecahan Masalah
Berdasarkan Langkah-Langkah Polya Pada Materi Turunan Fungsi Ditinjau Dari Kecerdasan LogisMatematis Siswa Kelas XI IPA SMAN 7 Surakarta Tahun Ajaran 2013/2014. Jurnal Pendidikan Matematika dan Matematika (JPMM) , 119-128.

Netriwati. (2016). Analisis Kemampuan Pemecahan Masalah Matematis Berdasarkan Teori Polya Ditinjau dari Pengetahuan Awal Mahasiswa IAIN Raden Intan Lampung. Al-Jabar: Jurnal Pendidikan Matematika , 181-190. Novianti, D. E., Khoirotunnisa, A. U., \& Indriani, A. (2017). Profil Pemecahan Masalah Matematika Dalam Menyelesaikan Permasalahan Pemrograman Linear Ditinjau Dari Kemampuan Komunikasi Matematis. JIPM (Jurnal Ilmiah Pendidikan Matematika), 53-59.

S, R. Z. (2019). Profil Kemampuan Pemecahan masalah Berbentuk Open-Ended Bahasan Pokok Soal Cerita Materi Sistem Pesamaan Linear Tiga Variabel (SPLTV) Di Kelas X MA At- Thohiriyah Ngantru Tulungagung.

Septian, A. (2017). Penerapan Geogebra Untuk Meningkatkan Kemampuan Pemecahan Masalah Matematis 


$\begin{array}{lrrr}\begin{array}{l}\text { Mahasiswa } \\ \text { Pendidikan }\end{array} \text { Matematika } & \text { Kombinatorik Matematis Siswa. } \\ \text { Universitas Suryakancana. Jurnal } & \text { AlphaMath, 58-65. } \\ \text { PRISMA } & \text { Universitas } & \text { Dalam P. A. (2013). Analisis Kesalahan } \\ \text { Suryakancana, 180-191. } & \text { Divergensi Tipe Membuktikan } \\ \text { Prini, Y., Argarini, D. F., \& } & \text { Pada Mahasiswa Matematika. } \\ \text { Yazidah, N. I. (2018). Analisis } & \text { Jurnal Pendidikan dan } \\ \text { Kesalahan Dalam Memecahkan } & \text { Pengajaran, 106-113. }\end{array}$

Masalah Kombinatorika Ditinjau

Dari Gaya Kognitif. Aksioma

Jurnal Pendidikan Matematika

FKIP Univ. Muhammadiyah

Metro , 114-123.

Sumargiyani, Yusnia, I., \& Adibah, Y.

(2019). Analisis Kesalahan Dalam

Menyelesaikan Soal Program

Linear Berdasarkan Teori

Newman. AdMathEdu, 105-114.

Wahyuddin. (2017). Analisis Kemampuan

Pemecahan Masalah Matematika

Ekonomi Ditinjau Dari

Kemampuan Berpikir Logis Pada

Mahasiswa. AdMathEdu , 211230.

Wahyuniar, S. L., \& Widyawati, S. (2017). Proses Berpikir Mahasiswa Dalam Menyelesaikan

Soal Kombinatorial Berdasarkan Kecerdasan Logis Matematis. Numerical: Jurnal Matematika dan Pendidikan Matematika , 103114.

Widiyastuti, E., \& Utami, S. (2017).

Deskripsi Kemampuan Berpikir

Yuwono, T., Supanggih, M., \& Ferdiani, R. D. (2018). Analisis Kemampuan Pemecahan Masalah Matematika dalam Menyelesaikan Soal Cerita Berdasarkan Prosedur Polya. Jurnal Tadris Matematika, 137-144.

Zulkarnain, I., \& Nurbiati, I. (2019). Pengaruh Kecerdasan Logis Matematis terhadap Kemampuan Pemecahan Masalah. 565-572. 
